\title{
An exploration study on factors influencing Iranian food industry
}

\author{
Naser Azad*, Seyed Mohsen Seyedaliakbar, Arash Hosseinzadeh and Ashkan Arabi
}

Department of Management, Islamic Azad University, South Tehran Branch, Tehran, Iran

\begin{tabular}{l}
\hline C H R O N I C L E \\
\hline Article history: \\
Received January 12, 2013 \\
Received in revised format \\
15 April 2013 \\
Accepted 16 April 2013 \\
Available online \\
April 172013 \\
\hline Keywords: \\
Factor analysis \\
Food industry \\
Critical factors \\
\hline
\end{tabular}

\section{A B S T R A C T}

\begin{abstract}
The proposed study of this paper present an empirical investigation to detect important factors impacting on food market using factor analysis. The proposed study designed a questionnaire, distributed among 207 customers who were regular customers of two food chains in city of Tehran, Iran named Shahrvand and Hyperstar. The results of our survey indicate that six major factors including brand loyalty, physical characteristics, pricing effects, performance characteristics, brand relationship and brand position influence food industry, significantly. In terms of the first factor, brand loyalty, "Trust", "Packaging design characteristics", "Competitive pricing strategy", "Stability in quality", "External relationships" and "Meeting expectations" are important factors in different categories.
\end{abstract}

(c) 2013 Growing Science Ltd. All rights reserved.

\section{Introduction}

The role of brands and branding in the new economy characterized by digitization and globalization are attracting considerable attention (Fernie, 1990; Dawar \& Parker, 1994; Dowling \& Uncles, 1997; Rowley, 2004). Morgan-Thomas and Veloutsou (2013) presented some insights on marketing and information systems research to build a framework of online brand experience. In their model, emotional characteristics of brand relationship supplemented the dimension of technology acceptance to reach at a comprehensive insight about consumer experience with an online brand. The empirical experiments involved structural equation modeling based on a survey of 456 users of online search engines. The results demonstrated that trust and perceived usefulness positively influenced online brand experience. Positive experiences result in satisfaction and behavioral intentions that in turn led to the formation of online brand relationship. In their survey, brand reputation emerged as an important antecedent of trust and perceived ease of implementation of an online brand (Sudhir, 2001).

Jones et al. (2010) explored the emergence and development of experience stores by considering their potential impact in fostering consumer brand relationships and their effect on the retail landscape.

*Corresponding author.

E-mail addresses: dr.naserazad@yahoo.com (N. Azad) 
They provided a comprehensive review of the emergence of experience stores and their effect in developing relationships between brands and consumers. Ha and Perks (2005) studied the effects of consumer perceptions of brand experience on the web by looking into brand familiarity, satisfaction and brand trust. They discussed that creating a customer experience that is synonymous with a particular website could be recognized as an essential driver of e-performance, increasingly.

E-tailors attempt to impact consumers' shopping behavior, through atmospherics and service, as brick-and-mortar stores. They investigated several unanswered questions in recent studies of consumer behavior in the context of internet-based marketing. The results of an empirical study of econsumer behavior demonstrated that brand trust was achieved through the following dimensions such as various brand experiences and the search for information, a high level of brand familiarity, and customer satisfaction based on cognitive and emotional factors (Rettie \& Brewer, 2000; Chattopadhyay \& Laborie, 2005). Dickson and Urbany (1994) investigated retailer reactions to competitive price changes. Gabisch and Gwebu (2011) examined the effect of virtual experiences on attitude formation, and offline purchase intentions, and detected three kinds of channel congruence including perceived diagnosticity, self-image congruence, and behavioral consistency, which could help describe the cross-channel effects (Underwood, 2001). They reported that multichannel impacts existed between virtual brand experiences and real-world purchasing decisions. According to Alloza (2008), Successful corporate brand management lies on sounded brand engagement and strategic alignment initiatives. Kim and Sullivan (1998) investigated the impact of parent brand experience on line extension trial and repeat purchase. Iglesias et al. (2011) studied the direct and indirect relationship between brand experience and brand loyalty. They investigated whether the relationship was mediated by affective commitment or not. The analysis recommended that affective commitment could mediate the relationship between brand experience and brand loyalty for all three product studied categories including cars, laptops and sneakers. The article extended the understanding of the brand experience construct by studying its impact on brand loyalty and by incorporating affective commitment as a mediating variable.

Morrison and Crane (2007) discussed why marketers of service brands must understand the emotional dynamics involved when a customer chooses and decides to continue to implement a service brand. It also presents practical guidance for how marketers are capable of building strong service brands by creating and managing emotional brand experiences. Hultén (2011) presented the multi-sensory brand-experience concept in association with the human minds and senses and tried to propose a sensory marketing (SM) model of the multi-sensory brand-experience hypothesis (Keller, 2011). The findings offered additional insights to managers on the multi-sensory brand-experience concept. Boo et al. (2009) examined empirical information to develop a destination brand model by investigating customer-based brand equity models through a scale purification process, ensuring its reliability and validity. Zarantonello and Schmitt (2010) used the brand experience scale to profile consumers and predict consumer behavior. Clatworthy (2012) described the development and evaluation of a process model to transform brand strategy into service experiences during the front end of new service development. O'Cass and Grace (2004) explored different consumer experiences with a service brand. Coulson (2000) presented an application of the stages of change model to consumer use of food labels. Méndez et al. (2006) analyzed price dispersion tools available to consumer goods manufacturers to obtain price consistency.

\section{The proposed study}

The proposed study of this paper attempts to detect important factors impacting on food market using factor analysis. The proposed study designed a questionnaire, distributed among 207 customers who were regular customers of two food chains in city of Tehran, Iran named Shahrvand and Hyperstar. The proposed study of this paper uses factor analysis to extract important factors. The questionnaire consists of 23 questions and since factor analysis is sensitive on skewness of data, we have decided to remove some of the questions including trust, profitability, reputation, customer relationship 
management, stores created experience, physical design of store, familiarity, satisfaction, face to face relationships, employee's behavior, perception image, social background, response to expectations, sustainability of brand, external advertisement, packaging design, quality of packaging, quality durability, access and price. Cronbach alpha was calculated as 0.797 , which is well above the minimum acceptable limit and validates the results. Table 1 shows details of some basic statistics,

\section{Table 1}

Descriptive Statistics

\begin{tabular}{|c|c|c|c|c|c|c|}
\hline & \multirow{2}{*}{$\begin{array}{l}\mathrm{N} \\
\text { Statistic }\end{array}$} & \multirow{2}{*}{$\begin{array}{l}\text { Range } \\
\text { Statistic }\end{array}$} & \multicolumn{2}{|c|}{ Skewness } & \multicolumn{2}{|c|}{ Kurtosis } \\
\hline & & & Statistic & Std. Error & Statistic & Std. Error \\
\hline$\overline{\text { VAR00001 }}$ & 206 & 4.00 & -.654 & .169 & 1.323 & .337 \\
\hline VAR00002 & 206 & 3.00 & -.156 & .169 & -.408 & .337 \\
\hline VAR00003 & 206 & 4.00 & -.339 & .169 & -.427 & .337 \\
\hline VAR00004 & 206 & 4.00 & -.662 & .169 & .333 & .337 \\
\hline VAR00005 & 206 & 4.00 & -.378 & .169 & -.222 & .337 \\
\hline VAR00006 & 206 & 4.00 & -.256 & .169 & -.513 & .337 \\
\hline VAR00007 & 206 & 4.00 & -.663 & .169 & .370 & .337 \\
\hline VAR00009 & 206 & 4.00 & -.654 & .169 & .344 & .337 \\
\hline VAR00010 & 206 & 4.00 & -.707 & .169 & -.040 & .337 \\
\hline VAR00011 & 206 & 4.00 & -.620 & .169 & .876 & .337 \\
\hline VAR00012 & 206 & 4.00 & -.092 & .169 & -.300 & .337 \\
\hline VAR00013 & 206 & 4.00 & .026 & .169 & -.165 & .337 \\
\hline VAR00014 & 206 & 4.00 & -.582 & .169 & .284 & .337 \\
\hline VAR00015 & 206 & 3.00 & -.196 & .169 & -.422 & .337 \\
\hline VAR00016 & 206 & 4.00 & -.114 & .169 & -.055 & .337 \\
\hline VAR00017 & 206 & 4.00 & -.366 & .169 & .404 & .337 \\
\hline VAR00018 & 206 & 4.00 & -.341 & .169 & -.265 & .337 \\
\hline VAR00019 & 206 & 3.00 & -.810 & .169 & -.096 & .337 \\
\hline VAR00020 & 206 & 4.00 & -.662 & .169 & .513 & .337 \\
\hline VAR00021 & 206 & 4.00 & -.397 & .169 & -.628 & .337 \\
\hline VAR00022 & 206 & 4.00 & -.898 & .169 & .194 & .337 \\
\hline $\begin{array}{l}\text { Normal Score of VAR00008 using Blom's } \\
\text { Formula }\end{array}$ & $S_{2} 206$ & 3.1447 & -.832 & .169 & -.163 & .337 \\
\hline $\begin{array}{l}\text { Normal Score of VAR00023 using Blom's } \\
\text { Formula }\end{array}$ & $S_{206}$ & 3.0526 & -.999 & .169 & -.037 & .337 \\
\hline Valid N (listwise) & 206 & & & & & \\
\hline
\end{tabular}

Table 2

Item-Total Statistics

\begin{tabular}{|c|c|c|c|c|c|}
\hline & $\begin{array}{l}\text { Scale Mean if Item } \\
\text { Deleted }\end{array}$ & $\begin{array}{l}\text { Scale Variance if Item } \\
\text { Deleted }\end{array}$ & $\begin{array}{l}\text { Corrected Item-Total } \\
\text { Correlation(1) }\end{array}$ & $\begin{array}{l}\text { Squared Multiple } \\
\text { Correlation(2) }\end{array}$ & $\begin{array}{l}\text { Cronbach's Alpha if } \\
\text { Item Deleted(3) }\end{array}$ \\
\hline$\overline{\text { VAR00001 }}$ & 75.676793 & 67.212 & .379 & .443 & .789 \\
\hline VAR00002 & 75.953492 & 67.476 & .326 & .301 & .791 \\
\hline VAR00003 & 76.074851 & 64.512 & .461 & .369 & .783 \\
\hline VAR00004 & 75.880677 & 66.125 & .345 & .231 & .790 \\
\hline VAR00005 & 76.069997 & 68.511 & .178 & .140 & .799 \\
\hline VAR00006 & 76.235045 & 65.056 & .367 & .260 & .788 \\
\hline VAR00007 & 75.836987 & 64.721 & .496 & .361 & .782 \\
\hline VAR00009 & 76.050579 & 67.060 & .261 & .147 & .795 \\
\hline VAR00010 & 75.701065 & 66.233 & .357 & .203 & .789 \\
\hline VAR00011 & 75.977764 & 67.299 & .314 & .218 & .791 \\
\hline VAR00012 & 76.696211 & 66.304 & .286 & .223 & .793 \\
\hline VAR00013 & 76.594269 & 68.225 & .195 & .164 & .798 \\
\hline VAR00014 & 75.841842 & 66.021 & .403 & .266 & .787 \\
\hline VAR00015 & 75.972910 & 64.464 & .561 & .422 & .779 \\
\hline VAR00016 & 76.536016 & 68.013 & .208 & .227 & .797 \\
\hline VAR00017 & 76.167084 & 66.059 & .387 & .458 & .787 \\
\hline VAR00018 & 76.065143 & 64.849 & .459 & .444 & .784 \\
\hline VAR00019 & 75.560288 & 66.022 & .412 & .382 & .786 \\
\hline VAR00020 & 75.953492 & 66.173 & .353 & .300 & .789 \\
\hline VAR00021 & 75.934075 & 67.801 & .215 & .371 & .797 \\
\hline VAR00022 & 75.662230 & 66.568 & .314 & .390 & .791 \\
\hline $\begin{array}{l}\text { Normal Score of VAR00008 } \\
\text { Blom's Formula }\end{array}$ & '79.874675 & 66.910 & .351 & .370 & .789 \\
\hline $\begin{array}{l}\text { Normal Score of VAR0002 } \\
\text { Blom's Formula }\end{array}$ & 9.884643 & 67.394 & .320 & .305 & .791 \\
\hline
\end{tabular}

In order to understand about the number of factors we draw Scree plot shown in Fig. 1 as follows, 


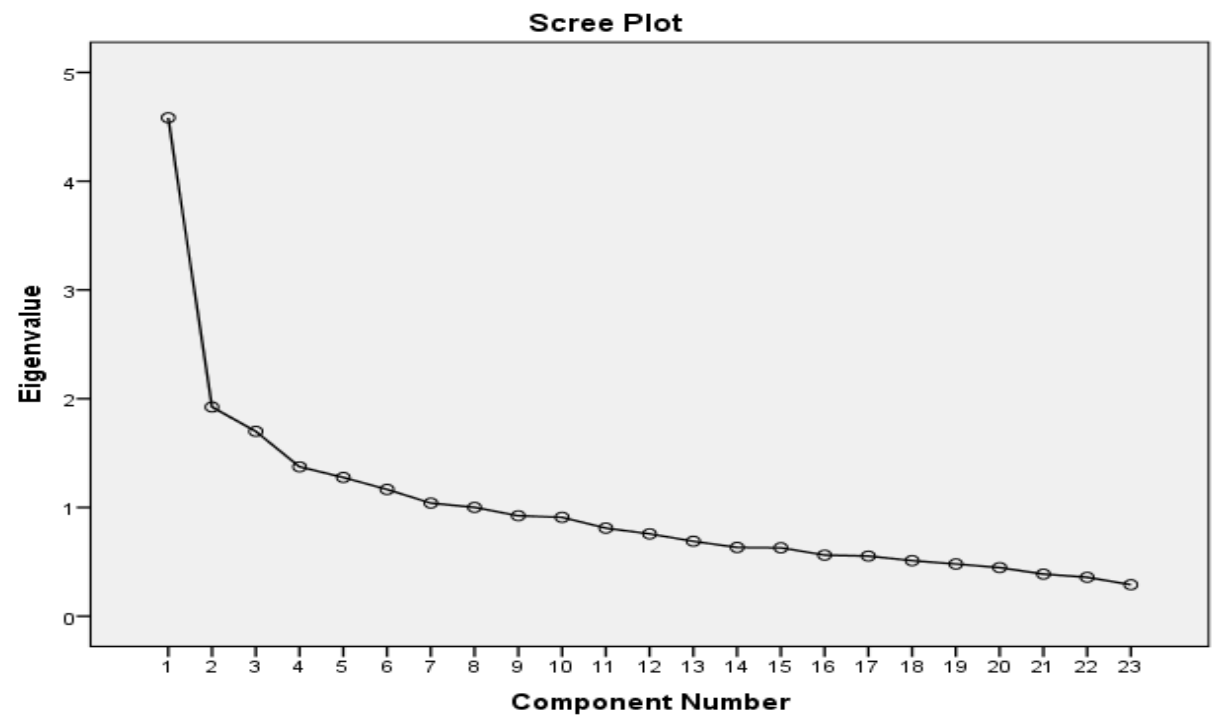

Fig. 1. The results of Scree plot

The result of Fig. 1 demonstrates that after six factors the trend becomes linear. Table 3 presents details of factor analysis before rotation implemented.

Table 3

The results of Principal Component Analysis before rotation

\begin{tabular}{|c|c|c|c|c|c|c|c|c|}
\hline & & & & Compo & nnent & & & \\
\hline & 1 & 2 & 3 & 4 & 5 & 6 & 7 & 8 \\
\hline VAR00015 & .673 & & & & & & & \\
\hline VAR00007 & .627 & & & & & & & \\
\hline VAROกก18 & 577 & & & & & & & \\
\hline VAR00003 & .574 & & & & & & & \\
\hline VAR00019 & .527 & & & -.361 & & & & \\
\hline VAR00001 & .524 & -.382 & & & & & & \\
\hline VAR00014 & .515 & & & & & & -.343 & \\
\hline Normal Score of VAR00008 using Blom's Formula & .481 & & -.436 & & & & & \\
\hline VAR00006 & .454 & & .381 & & & & & \\
\hline VAR00010 & .444 & & & & & & & \\
\hline VAR00002 & .433 & -.383 & & & & .366 & & \\
\hline VAR00004 & .432 & & & & .416 & & & \\
\hline VAR00021 & & .694 & & & & .373 & & \\
\hline VAR00022 & .350 & .675 & & & & & & \\
\hline VAR00020 & .406 & .474 & & & & & & \\
\hline VAR00017 & .495 & & .576 & & & & & \\
\hline VAR00016 & & & .511 & & .427 & & & -.345 \\
\hline Normal Score of VAR00023 using Blom's Formula & .390 & .401 & -.456 & & & & & \\
\hline VAR00012 & & & & .660 & & & & \\
\hline VAR00005 & & & & .589 & & & .492 & \\
\hline VAR00011 & .402 & & & & $-.424-$ & $4-.336$ & & \\
\hline VAR00013 & & & & & $.436-$ & -.494 & & .455 \\
\hline VAR00009 & & & & & .347 & & & -.474 \\
\hline
\end{tabular}

We have used principal component analysis using Varimax with Laiser normalization. Based on the results of principal component analysis, there are eight factors including brand loyalty, physical characteristics, price effects, performance characteristics, brand relationship and brand position and Table 4 shows details of our survey. 
Table 4

The results of Principal Component Analysis using Varimax with Kaiser Normalization

\begin{tabular}{|c|c|c|c|c|c|c|c|c|}
\hline & \multicolumn{8}{|c|}{ Component } \\
\hline & 1 & 2 & 3 & 4 & 5 & 6 & 7 & 8 \\
\hline VAR00001 & .832 & & & & & & & \\
\hline Normal Score of VAR00008 using Blom's Formula & 642 & & & & & & & \\
\hline VAR00003 & .568 & & & & & & & \\
\hline VAR00002 & .550 & & & & & & & \\
\hline VAR00014 & .504 & & & & & & & \\
\hline VAR00007 & .441 & & & .434 & & & & \\
\hline VAR00017 & & & & & & & & \\
\hline VAR00018 & & & & & & & & \\
\hline VAR00015 & .339 & & & & & & & \\
\hline VAR00006 & & & & & & & & \\
\hline \multicolumn{9}{|l|}{ VAR00010 } \\
\hline VAR00021 & & & .838 & & & & & \\
\hline VAR00022 & & & .774 & & & & & \\
\hline VAR00020 & & & .540 & .363 & & & & \\
\hline VAR00019 & & & & .774 & & & & \\
\hline Normal Score of VAR00023 using Blom's Formula & & & .373 & .576 & & & & \\
\hline VAR00011 & \multicolumn{8}{|c|}{.718} \\
\hline VAR00012 & & & & & & & & .389 \\
\hline VAR00016 & & & & \multicolumn{5}{|c|}{.739} \\
\hline VAR00009 & & & & \multicolumn{5}{|c|}{.523} \\
\hline VAR00005 & & & & & \multicolumn{4}{|c|}{.825} \\
\hline VAR00013 & & & & & & & & .888 \\
\hline VAR00004 & .336 & & & .363 & & & & .430 \\
\hline
\end{tabular}

\section{The results}

The proposed study of this paper has determined six major factors using factor analysis and in this section, we present details of our findings.

\subsection{The first factor: Brand loyalty}

The first factor, "Brand loyalty” includes four components including "trust”, "Customer satisfaction”, "Perception profitability" and "Brand awareness" and the results are summarized in Table 5.

\section{Table 5}

The summary of factors associated with brand loyalty

\begin{tabular}{lcccc}
\hline \multicolumn{1}{c}{ Option } & Factor weight & Eigenvalue & \% ofvariance & Accumulated \\
\hline Trust & .832 & 4.583 & 19.927 & 19.927 \\
Customer satisfaction & .642 & & & \\
Perception profitability & .550 & & & \\
Brand awareness & .504 & & & \\
\hline Cronbach alph $=0.789$ & & & &
\end{tabular}

It is evident from the results of Table 5 that "Trust" is number one priority followed by "Customer satisfaction", "Perception profitability" and "Brand awareness". Cronbach alpha has been calculated as 0.789 , which validates the results of our survey.

\subsection{The second factor: Physical characteristics}

Physical characteristics is an essential factor and plays important role for the success of any marketing planning in food industry. This factor includes four factors including "Packaging design characteristics", "Quality of packaging”, "Brand revokes", and "Physical design of stores" and the results of factor analysis are given in Table 6 as follows, 


\section{Table 6}

The summary of factors associated with compatibility

\begin{tabular}{lcccc}
\hline Option & Factor weight & Eigenvalue & \% ofvariance & Accumulated \\
\hline Packaging design characteristics & .812 & 0.533 & 2.404 & 89.247 \\
Quality of packaging & .728 & & & \\
Brand revokes & .577 & & & \\
Physical design of stores & .495 & & & \\
\hline Cronbach alph $=0.787$ & & & &
\end{tabular}

According to the results of Table 6, "Packaging design characteristics" is the most important factor followed by "Quality of packaging”, "Brand revokes" while "Physical design of stores" is the last priority.

\subsection{The third factor: Pricing effects}

Pricing effects is the third important factor influencing food industry, which includes three factors including "Competitive price", "Price stability", and "Product availability". Table 7 demonstrates details of our survey where "Competitive pricing strategy" plays essential role on marketing food industry followed by "Price stability".

\section{Table 7}

The summary of factors associated with pricing effects

\begin{tabular}{lcccc}
\hline Option & Factor weight & Eigenvalue & \% ofvariance & Accumulated \\
\hline Competitive pricing strategy & .838 & 0.387 & 1.685 & 97.186 \\
Price stability & .774 & & & \\
Product availability & .540 & & & \\
\hline
\end{tabular}

Cronbach alph $=0.719$

\subsection{The fourth factor: Performance characteristics}

Performance characteristics components is the next factor, which influences food marketing and it includes three factors summarized in Table 8 as follows,

\section{Table 8}

The summary of factors associated with performance characteristics

\begin{tabular}{|c|c|c|c|c|}
\hline Option & Factor weight & Eigenvalue & \% ofvariance & Accumulated \\
\hline Brand awareness & .434 & & & \\
\hline Stability in quality & .774 & 0.480 & 2.089 & 93.557 \\
\hline Minimum price, maximum productivity & .576 & & & \\
\hline
\end{tabular}

Cronbach alph $=0.786$

Based on the results of Table 8, "Stability in quality" is the most important factor followed by "minimum price, maximum productivity" and "brand awareness".

\subsection{The fifth factor: Brand relationship}

Brand relationship is the next factor, which influences food marketing including three factors summarized in Table 9 as follows,

\section{Table 9}

The summary of factors associated with brand relationship

\begin{tabular}{lcccc}
\hline Option & Factor weight & Eigenvalue & \% ofvariance & Accumulated \\
\hline Brand reputation & .408 & & & \\
External relationships & .739 & 0.562 & 2.443 & 86.843 \\
Face to face relationship & .523 & & & \\
\hline
\end{tabular}

Cronbach alph $=0.797$ 
Based on the results of Table 9, "External relationships" is the most important factor followed by "face to face relationship" and "brand reputation”.

\subsection{The sixth factor: Brand position}

Brand position is the last factor, which influences food marketing and it includes three factors summarized in Table 10 as follows,

\section{Table 10}

The summary of factors associated with brand position

\begin{tabular}{lcccc}
\hline Option & Factor weight & Eigenvalue & \% ofvariance & Accumulated \\
\hline Social position & .389 & & & 78.916 \\
Meeting expectations & .888 & 0.689 & 2.997 & \\
Customer relationship management & .430 & & & \\
\hline Cronbach alph $=0.798$ & & & &
\end{tabular}

Based on the results of Table 10, "Meeting expectations" is the most important factor followed by "Customer relationship management" and "Social position".

\section{Discussion and conclusion}

In this paper, we have presented an empirical investigation using principal component analysis to detect important factors influencing brand position. The results of our survey have revealed six major factors including brand loyalty, physical characteristics, pricing effects, performance characteristics, brand relationship and brand position. In terms of the first factor, brand loyalty, "Trust" is number one priority followed by "Customer satisfaction", "Perception profitability" and "Brand awareness". In terms of the second factor, physical characteristics, "Packaging design characteristics" is the most important factor followed by "Quality of packaging", "Brand revokes" while "Physical design of stores" is the last priority. In terms of pricing effects, our survey indicate that "Competitive pricing strategy" plays essential role on marketing food industry followed by "Price stability". In terms of performance characteristics, "Stability in quality" is the most important factor followed by "minimum price, maximum productivity" and "brand awareness". Brand relationship is another influencing factor on food industry where "External relationships" in this category is the most important factor followed by "face to face relationship" and "brand reputation". Finally, brand position, is the last factor in our analysis where "Meeting expectations" is the most important factor followed by "Customer relationship management” and "Social position”.

\section{Acknowledgment}

The authors would like to thank anonymous referees for constructive comments on earlier version of this paper.

\section{References}

Alloza, A. (2008). Brand engagement and brand experience at BBVA, the transformation of a 150 years old company. Corporate Reputation Review, 11(4), 371-379.

Boo, S., Busser, J., \& Baloglu, S. (2009). A model of customer-based brand equity and its application to multiple destinations. Tourism Management, 30(2), 219-231.

Clatworthy, S. (2012). Bridging the gap between brand strategy and customer experience. Managing Service Quality, 22(2), 108-127.

Coulson, N. S. (2000). An application of the stages of change model to consumer use of food labels. British Food Journal, 102(9), 661-668. 
Chattopadhyay, A., \& Laborie, J. L. (2005). Managing brand experience: the market contact audit. Journal of Advertising Research, 45(01), 9-16.

Dawar, N., \& Parker, P. (1994). Marketing universals: consumers' use of brand name, price, physical appearance, and retailer reputation as signals of product quality. The Journal of Marketing, 81-95.

Dickson, P. R., \& Urbany, J. E. (1994). Retailer reactions to competitive price changes. Journal of Retailing, 70(1), 1-21.

Dowling, G. R., \& Uncles, M. (1997). Do customer loyalty programs really work?. Research Brief, 1.

Fernie, J. (1990). International Journal of Retail \& Distribution Management. Marketing Intelligence \& Planning, 8(5), 7-8.

Gabisch, J. A., \& Gwebu, K. L. (2011). Impact of virtual brand experience on purchase intentions: The role of multichannel congruence. Journal of Electronic Commerce Research, 12(4), 302-319.

Ha, H. Y., \& Perks, H. (2005). Effects of consumer perceptions of brand experience on the web: Brand familiarity, satisfaction and brand trust. Journal of Consumer Behaviour, 4(6), 438-452.

Hultén, B. (2011). Sensory marketing: the multi-sensory brand-experience concept. European Business Review, 23(3), 256-273.

Iglesias, O., Singh, J. J., \& Batista-Foguet, J. M. (2011). The role of brand experience and affective commitment in determining brand loyalty. Journal of Brand Management, 18(8), 570-582.

Keller, K. L., Parameswaran, M. G., \& Jacob, I. (2011). Strategic brand management: Building, measuring, and managing brand equity. Pearson Education India.

Kim, B. D., \& Sullivan, M. W. (1998). The effect of parent brand experience on line extension trial and repeat purchase. Marketing Letters, 9(2), 181-193.

Méndez, J. L., Oubiña, J., \& Rubio, N. (2006). Explanatory factors regarding manufacturer brand price consistency. Journal of Product \& Brand Management, 15(6), 402-411.

Morgan-Thomas, A., \& Veloutsou, C. (2011). Beyond technology acceptance: Brand relationships and online brand experience. Industrial Marketing Management, 66(1), 21-27.

Morrison, S., \& Crane, F. G. (2007). Building the service brand by creating and managing an emotional brand experience. Journal of Brand Management, 14(5), 410-421.

Jones, P., Comfort, D., Clarke-Hill, C., \& Hillier, D. (2010). Retail experience stores: experiencing the brand at first hand. Marketing Intelligence \& Planning, 28(3), 241-248.

O'Cass, A., \& Grace, D. (2004). Exploring consumer experiences with a service brand. Journal of Product \& Brand Management, 13(4), 257-268.

Rettie, R., \& Brewer, C. (2000). The verbal and visual components of package design. Journal of Product \& Brand Management, 9(1), 56-70.

Rowley, J. (2004). Online branding. Online Information Review, 28(2), 131-138.

Sudhir, K. (2001). Competitive pricing behavior in the auto market: A structural analysis. Marketing Science, 20(1), 42-60.

Underwood, R. L., Klein, N. M., \& Burke, R. R. (2001). Packaging communication: attentional effects of product imagery. Journal of Product \& Brand Management, 10(7), 403-422.

Zarantonello, L., \& Schmitt, B. H. (2010). Using the brand experience scale to profile consumers and predict consumer behaviour. Journal of Brand Management, 17(7), 532-540. 